an order preventing identification of the complainant or her family, with a penal notice attached. [WA]

A transcript of the tribunal's determination may be found at http://www.ecclaw.co.uk/ clergydiscipline/okechi1.pdf and of the imposition of penalty at http://www.ecclaw. co.uk/clergydiscipline/okechi2.pdf

\title{
London Borough of Islington v Ladele
}

Employment Appeal Tribunal: Elias J, December 2008

Registrar - civil partnerships - conscientious objection - dismissal

The Employment Appeal Tribunal allowed the council's appeal against the Employment Tribunal's finding that Ms Ladele, a registrar, had suffered direct and indirect discrimination and harassment on the grounds of religion or belief after having been disciplined by the council for refusing to perform civil partnership ceremonies. ${ }^{7}$ In relation to the claim of direct discrimination, the EAT noted that the crucial question for the tribunal to determine had been why the claimant had been treated as she was. The lower tribunal's analysis betrayed a number of errors of law: it had not been proved that the claimant had been treated in this way because of her religion or belief. The council had not treated the claimant differently from others but had refused to make an exception for her because of her religious convictions. The complaint was of a failure to accommodate difference rather than a complaint that she had been discriminated against because of that difference. Treating all employees in precisely the same way could not constitute direct discrimination. The EAT found that the tribunal had confused the claimant's reasons for acting as she did (which were on grounds of religion) with the respondent's reasons for treating the claimant as it had (which were on grounds of her conduct, not of her belief).

This same reasoning applied in relation to the claim of harassment. It had not been proven that the harassment was on grounds of religion or belief. It was not sustainable reasoning to hold that because the claimant was asserting a religious view and suffered unwanted conduct as a consequence then that conduct must be deemed to be by reason of the religious view. The EAT noted that to hold that because the claimant's conduct was on grounds of her religion or belief that necessarily meant that she was being discriminated against on religious grounds would mean that 'the religious belief would be a solvent dissolving all inconsistent legal obligations owed to the employer'. 
In relation to indirect discrimination, it was accepted that the respondent's requirement that all registrars should perform civil partnership ceremonies had the effect of placing persons of the claimant's religion or belief at a particular disadvantage and personally disadvantaged her. Since it was accepted that the promotion of equal opportunities and fighting discrimination was a legitimate aim, the key issue was whether it was proportionate. The EAT held that the tribunal had wrongly applied the proportionality test. The tribunal had held that it was not proportionate on the basis that the respondent had placed greater value on the rights of the gay community than on the rights of orthodox Christians. The EAT held that this was an erroneous approach: the question of proportionality was not a matter of giving equal respect to different communities, but of whether or not the means adopted to achieve a legitimate aim were proportionate. That test had been met. Requiring staff to act in a non-discriminatory manner was rationally connected with the legitimate aim and reasonably necessary to achieve that aim. Although Parliament had, in certain areas, permitted religious beliefs to take priority over the claims of those who sought not to be discriminated against on grounds of sexual orientation, such exceptions should be narrowly construed and no special exception had been carved out in respect of civil partnership duties. The EAT was also satisfied that its analysis was not inconsistent with Article 9 of the European Convention on Human Rights, which had adopted 'a very narrow protection indeed for employees'. There was thus 'no real doubt' that there would be any breach of Article 9 in this case. The argument advanced by Rix LJ in Copsey $v$ WBB Devon Clays Ltd [2005] EWCA Civ 932 that the line of authority did not apply when contractual variations were later imposed by the employer was unlikely to succeed here, where the extension of duties had been made by Parliament.

Summary supplied by Russell Sandberg. A fuller version appeared in Law and Justice, and it is reproduced here with permission.

\section{Archdeacon of Rochester v Tripp and Northern}

Disciplinary Tribunal, Diocese of Rochester, December 2008 Adultery - desertion - public scandal - penalty

The respondents, who were, respectively, Rector and Associate Rector of the same benefice, admitted deserting their respective spouses and setting up home together. The tribunal therefore considered only the penalty to be imposed. The Bishop of Rochester recommended that both be prohibited from ministry for life, on the grounds that abandoning their parish without 